\section{Nastrój nowoczesności. Doświadczenie filmu, nowe sposoby widzenia i optymizm w archiwum Pierre'a Francastela}

Andrzej Leśniak
Publikacja powstała dzięki realizacji Działania sfinansowanego ze środków Narodowego Centrum Nauki (numer rejestracyjny Działania: 2017/01/X/HS2/00887).

TEKSTY DRUGIE 2018, NR 6, S. 92-109

DOI: $10.18318 /$ td.2018.6.6

$\mathbf{N}_{\mathrm{r}}^{\circ}$ owoczesność nie sprowadza się do idei dotyczących rozumu,tradycji i historii.Doświadczenie nowoczesności może być doświadczeniem nastroju: entuzjazmu, optymizmu, poczucia konieczności zaangażowania się we współczesność, bycia odpowiedzialnym wobec własnego czasu. W niniejszym tekście pokazuję, że archiwum Pierre'a Francastela (1900-1970), zapomnianego francuskiego socjologa i historyka sztuki, jest miejscem tego rodzaju doświadczenia. Zgromadzony w nim dorobek okazuje się istotny dla badaczy nowoczesności nie tylko ze względu na tematykę (kluczowym przedmiotem badań Francastela były związki techniki i kultury nowoczesnej), lecz także dlatego, że wytwarza to, co nazwałbym nastrojem nowoczesności. Mam na myśli afektywne nacechowanie zbioru dokumentów, mającą materialną podstawę atmosferę, której nie da się sprowadzić do znaczenia interpretowanych tekstów.

Dorobek Pierre'a Francastela pozostaje w cieniu innych osiągnięć XX-wiecznej francuskiej humanistyki i nauk społecznych. Choć autor Sztuki i techniki jest wymieniany w niektórych opracowaniach historii socjologii
Andrzej Leśniak prof. nadzwyczajny w Instytucie Badań Literackich PAN. Autor trzech książek: Ikonofilia. Francuska semiologia pikturalna i obrazy (2013), Obraz płynny. Georges Didi-Huberman idyskurs historii sztuki (2010), Topografie doświadczenia: Maurice Blanchot i Jacques Derrida (2003). Redaktor (wspólnie z Grzegorzem Piątkiem) zbioru tekstów Rema Koolhaasa (Śmieciowa przestrzeń. Teksty, 2017) oraz polskich wydań Le Corbusiera (Kiedy katedry były białe, 2013 i Wstronę architektury, 2012). 
sztuki we Francji jako postać istotna, najczęściej jako jeden z ojców-założycieli nurtu socjologicznych badań nad sztuką', nie sposób nie skonstatować, że założycielska rola Francastela nie przełożyła się na ukształtowanie się znaczącej formacji intelektualnej bezpośrednio czerpiącej inspirację z jego pism, identyfikującej się z zadaniem kontynuowania jego pracy. Francastel zainicjował badania w obrębie socjologii sztuki, a proponowana przez niego orientacja teoretyczna miała wpływ na współczesny kształt dyscyplin, których przedmiotem jest sztuka. Dodatkowo niektóre spośród jego idei są podskórnie obecne w XX- i XXI-wiecznej myśli o obrazach. Ale jego koncepcja jako taka nie stała się nigdy decydująca czy formująca dla kolejnych pokoleń badaczy; nigdy nie powstała żadna „szkoła Francastela”. Dopiero w ostatnich latach rozpoznaje się prekursorski charakter jego prac: przy okazji angielskiego wydania Sztuki i techniki w 2000 roku Yve-Alain Bois poświęcił Francastelowi krytyczny wstęp, wskazując na oryginalną koncepcję nowoczesności², a w 2010 roku w paryskim Institut National d'Histoire de l'Art urządzono wystawę zatytułowaną Pierre Francastel. L'hypothèse même de l'art. Towarzyszący jej katalog ${ }^{3}$ pod redakcją kuratora, Thierry'ego Dufrêne'a, gromadzi ważne teksty dotyczące kluczowych motywów badań Francastela. Sam Dufrêne pisze o jego pracach jako zapowiadających zwrot antropologiczny w badaniach nad sztuką. „[...] wystawa i konferencja w INHA to propozycje powrotu do Francastela «żyjącego», jak mawiał Fernand Braudel; choć podręczniki historii sztuki wydawane we Francji w ostatnich dziesięcioleciach zwykle pomijają jego prace, nie sposób nie skonstatować, że Francastel wytyczył szlak dla historii sztuki jako jednego z filarów antropologii kulturowej przed pojawieniem się prac Michaela Baxandalla, Davida Friedberga i Hansa Beltinga $[. . .]^{\prime \prime 4}$. Możliwe jest też prześledzenie tych elementów prac francuskiego badacza, które zapowiadają późniejsze przemiany w myśli o sztuce, przede wszystkim te, dzięki którym sztuka zostanie uznana za miejsce myśli, za fenomen obdarzony zdolnością generowania refleksji5

1 Zob. B. Péquignot La sociologie de l'art et de la culture en France: un état des lieux, "Sociedade e Estado" 2005 vol. 20, n. 2, s. 303-335. oraz tegoż Sociologie des arts, Arman Colin, Paris, 2009.

2 Y.A. Bois Foreword, w: P. Francastel Art \& Technology in the Nineteenth and Twentieth Centuries, trans. R. Cherry, Zone Books, New York 2000.

3 Pierre Francastel. L'hypothèse même de l'art, red. T. Dufrêne, INHA, Paris 2010.

4 T. Dufrêne Lire Francastel aujourd'hui. L'historien de l'expérience artistique, w: Pierre Francastel..., s. 18.

5 Zob. A. Leśniak Myślenie plastyczne. Mediacja techniki w sztuce według Pierréa Francastela, "Konteksty. Polska Sztuka Ludowa" 2018 nr 4 [w druku] 
Status „niedocenionego prekursora” ma w przypadku Francastela przynajmniej dwie przyczyny. Pierwsza z nich wiąże się z układem koniunktur na akademickim rynku idei. W obrębie nauk społecznych francuska scena intelektualna została zdominowana już w latach 6o. przez Pierre'a Bourdieu i - ogólniej - socjologię krytyczną. Choć dzieliła z Francastelem strukturalistyczne źródła, rozwinęła się w innym kierunku - w kierunku praktyki uzasadnionej przede wszystkim koniecznością rozpoznawania, opisywania, denuncjowania zjawiska dominacji na różnych płaszczyznach życia społecznego, a ostatecznie zadaniem zaangażowania politycznego. W artykule dotyczącym losów dziedzictwa intelektualnego Francastela w polu francuskiej socjologii sztuki Alain Quemin i Clara Levy ${ }^{6}$ piszą o niewielkiej liczbie odniesień do pism autora Sztuki i techniki w kluczowych dziełach dyscypliny: $\mathrm{w}$ Le marche de la peinture en France ${ }^{7}$ Raymonde Moulin i w L'amour de l'art. Les musées d'art européens et leur public ${ }^{8}$ Pierre'a Bourdieu i Alaina Darbela. Czas ich wydania to końcowy okres życia Francastela i jednocześnie moment, w którym socjologia sztuki konstytuuje się jako wyrazista subdyscyplina badań społecznych; już na tym etapie bohater tego tekstu został zmarginalizowany. Alain Quemin i Clara Levy nie podają jednak przyczyn takiego stanu rzeczy; zadowalają się konstatacją o nikłej ilości odwołań. Moim zdaniem odpowiedzią jest tutaj relacja między dziełem Francastela i ekspansją socjologii krytycznej, której triumfalny pochód zatrzyma się dopiero dwadzieścia lat później (i odżyje „dzięki” efektom kryzysu finansowego pierwszej dekady XXI wieku). Stworzony przez Francastela paradygmat nie współgrał z krytyczną perspektywą opisu tego, co społeczne. Innymi słowy, problemem jest miejsce francuskiego badacza na scenie intelektualnej i dynamika idei: nieoczywistość związku między historią sztuki i socjologią oraz problem możliwości przejścia od tradycyjnej, konserwatywnej dyscypliny historycznej ku nowoczesnej praktyce badawczej.

Drugą przyczyną słabej recepcji autora Sztuki i techniki stała się niewystarczająca radykalność proponowanego modelu socjologii sztuki widoczna wyraźniej w zestawieniu z projektami socjologii krytycznej. Wprawdzie Francastel usiłuje unowocześnić perspektywę historii sztuki, otworzyć ją na

6 Zob. A. Quemin, C. Levy La fortune critique de Pierre Francastel en sociologie de l'art en France: un héritage limité, w: Pierre Francastel...

7 R. Moulin Le marché de la peinture en France, Éditions de Minuit, Paris 1967.

8 P. Bourdieu, A. Darbel L'amour de l'art. Les musées d'art européens et leur public, Éditions de Minuit, Paris 1969. 
to, co społeczne, ale wciąż pozostaje zbyt związany z modelem poznawczym konserwatywnej dyscypliny historycznej. Jak tylko opuszcza jej bezpieczne terytorium, popada w ogólność, nie jest w stanie uzasadnić swych daleko idących ujęć syntetycznych. Innymi słowy, za niepopularność Francastela odpowiada skłonność francuskiego badacza do generalizacji i ujęć opartych na słabej podbudowie empirycznej - ta tendencja w myśli Francastela, albo nawet cecha jego pisarstwa, wynikająca wprost z balansowania między różnymi tradycjami dyscyplinarnymi, została już wstępnie zdiagnozowana przez jednego z najbardziej nieprzychylnych komentatorów. We wczesnym, pochodzącym z 1968 roku wprowadzeniu do numeru „International Social Science Journal" poświęconego sztuce w społeczeństwie Alphons Silbermann cytuje Francastela tylko po to, by z dystansem skonstatować, że „interesuje go bardziej zachowanie tradycji niż poszukiwanie postępu intelektualnego" Ta surowa opinia uzasadniona jest przez odwołanie do opozycji między empirią i systemem: z perspektywy Silbermanna praktyka socjologiczna oderwana od empirii z konieczności popada w dogmatyzm: zamiast stanowić wkład w rozwój wiedzy o współczesnym społeczeństwie, stanowi raczej świadectwo przywiązania do misji zachowywania i interpretowania przeszłości. Dla Silbermanna Francastel jest po prostu za mało nowoczesny; nawet jeśli jego prace dotyczą sztuki nowoczesnej i osadzają ją w przemianach technicznych i społecznych II połowy XIX i XX wieku, a więc tak naprawdę legitymizują artystyczny modernizm, w gruncie rzeczy są jedyne realizacją ambicji historycznej eksplikacji tej formacji artystycznej.

Choć pogląd Silbermanna wydaje się dobrze uzasadniony, nie zamyka on innych odczytań prac Francastela. W niniejszym tekście zapytam o nowoczesność Francastela, wskazując na te elementy jego dorobku, które nie były dotychczas eksplorowane albo sytuowały się na marginesie zainteresowań interpretatorów: badania nad nowymi sposobami widzenia wytwarzanymi przez medium filmowe oraz zaangażowanie w projekt filmologii - dyscypliny naukowej mającej zajmować się filmem, powstałej we Francji na przełomie lat 40.i 50. minionego wieku. Chciałbym zatem - wykorzystując doświadczenie pracy z archiwum, w którym zgromadzono dorobek Francastela - uzupełnić to, co o francuskim badaczu powiedziano do tej pory. Odwołam się do metody historycznego perspektywizmu, która pozwala na analizę znaczenia pojęć dzięki rozszerzeniu zakresu badań archiwalnych. Historyczny perspektywizm

9 A. Silbermann Introduction. A definition of the sociology of art, "International Social Science Journal" 1969 Vol. XX, No. 4, s. 568. 
jest współczesną odpowiedzią na dylematy w polu metodologii badań historyczno-filozoficznych sformułowaną przez Mogensa Laerke w tekście The Anthropological Analogy and the Constitution of Historical Perspectivism ${ }^{10} \mathrm{z} 2013$ roku. Laerke proponuje ugruntowanie badań historycznych dzięki zdefiniowaniu tzw. perspektyw wewnętrznych, czyli dyskusji, kontrowersji czy niejasności pojawiających się wokół pojęć należących do właściwego kontekstu historycznego. Dyskusje te dają się zrekonstruować dzięki analizie możliwie pełnego korpusu tekstów danego autora; chodzi przy tym zarówno o materiały opublikowane, jak i o nieopublikowane. Dodatkowo, w zakres analizowanych materiałów powinny wejść komentarze do opublikowanych tekstów. Sens historycznego perspektywizmu polega więc na poszerzeniu zakresu badań o materiały pozwalające na lepsze ugruntowanie znaczenia pojęć. Ta metoda ma istotne konsekwencje: znaczenie nie jest w jej ramach rozumiane w sposób statyczny, jako coś trwałego, oczekującego na odkrycie, ale jako dynamiczna całość, modyfikowana zarówno przez pojawiające się komentarze, jak i przez pracę samego autora, który rekontekstualizuje swoje wcześniejsze propozycje. Historyczny perspektywizm zdaje sprawę $\mathrm{z}$ dynamicznego charakteru pojęć; wydaje się z tego powodu racjonalną alternatywą wobec zarówno wszelkich postaci esencjalizmu (w ramach których znaczenia są historycznie niezmienne), jak i niektórych, najbardziej radykalnych wersji myślenia anachronicznego czy konstruktywistycznego opartych na przekonaniu o zawsze twórczym charakterze interpretacji materiałów historycznych. W przypadku Francastela inspiracja metodą historycznego perspektywizmu ma także uzasadnienie czysto praktyczne. W jego przypadku nie jesteśmy ograniczeni dostępnością korpusu, możemy wyjść poza lekturę tekstów opublikowanych, prześledzić ich genealogię, zapoznać się z materiałami mającymi zwykle status drugorzędnych: notatkami, zapiskami z wykładów, tekstami nieukończonymi, korespondencją. Możemy łatwo zrewidować dotychczas rozpowszechnione, dominujące interpretacje, lepiej je ugruntować w materiale źródłowym albo uzupełnić o takie wymiary, które wcześniej nie były brane pod uwagę.

Dorobek Francastela jest dostępny dzięki depozytowi złożonemu przez spadkobierców w Institut National d'Histoire de l'Art w Paryżu. W bibliotece INHA znajduje się 86 pudeł archiwalnych zawierających dokumenty osobiste,

10 Zob. M. Laerke The Anthropological Analogy and the Constitution of Historical Perspectivism, w: Philosophy and Its History: Aims and Methods in the Study of Early Modern Philosophy, ed. by M. Laerke, J.E.H. Smith, E. Schliesser, Oxford University Press, Oxford 2013. 
korespondencję, wycinki prasowe, notatki do zajęć, ogłoszenia o wykładach, manuskrypty, materiały do książek, prace tłumaczeniowe, dokumenty związane z udziałem w konferencjach naukowych i z projektami wydawniczymi, odbitki nadsyłanych artykułów, a także materiały ikonograficzne. Choć trudno zakładać, że ów depozyt zawiera całość dorobku badacza - tego nigdy się nie dowiemy - zapoznając się z wielką ilością dokumentów składających się na dorobek, nie sposób nie odnieść wrażenia przekraczania ograniczeń związanych z lekturą tekstów opublikowanych. Archiwum w tym przypadku umożliwia zniuansowanie interpretacji, a przede wszystkim rewizję standardowego odczytania, w ramach którego Francastel wprawdzie usiłował unowocześnić sposób myślenia o sztuce uświęcony w ramach dyscypliny historycznej, ale nie był wystarczająco konsekwentny, by stworzyć prawdziwie nowoczesną wizję kultury. Badania archiwalne w tym przypadku umożliwiają poszerzenie pola badań o dokumenty będące świadectwem poszukiwań autora, takie jak notatki do nieopublikowanych dzieł, teksty wykładów, które ostatecznie nie stały się rozdziałami książek, ale też inne materiały dowodzące stosunku Francastela do nowoczesności w sposób mniej oczywisty: ślady zaangażowania w inicjatywy naukowe czy emocjonalnie nacechowaną korespondencję z badaczami i artystami, którzy mieli wpływ na jego wizję świata. Innymi słowy, będę wykorzystywał metodę historycznego perspektywizmu, nie tylko poszerzając zakres komentowanych tekstów (choć jest to najbardziej oczywisty, skuteczny i uzasadniony element strategii interpretacyjnej) czy sięgając do słabo znanych komentarzy, ale też analizując takie świadectwa zaangażowania w nowoczesność, których nie da się do końca sprowadzić do wymiaru tekstualnego: mam tu przede wszystkim na myśli mające swe materialne podstawy momenty nacechowania afektywnego.

Moja hipoteza jest następująca: odpowiedź na pytanie o nowoczesność Francastela będzie najbardziej wiarygodna nie wtedy, gdy weźmie się pod uwagę wszystkie jego teksty ani nawet pod warunkiem uwzględnienia pełnego korpusu komentarzy, ale wtedy, gdy zostanie ona oparta także na opisie tego, co decyduje o afektywnym kształcie archiwum. Nie będę jednak stosował kategorii archiwum afektywnego, która funkcjonuje już w humanistyce w kontekście performatywnym ${ }^{11}$. Jej obecne znaczenie („proces budowania pamięci, w który zaangażowany jest każdy") jest dla moich potrzeb zbyt szerokie; przez jej pryzmat myślana jest współczesna kultura jako całość,

11 Zob. Leksykon archiwum afektywnego, red. K. Tórz, słowo/obraz terytoria, Narodowy Instytut Audiowizualny, Gdańsk-Warszawa 2015. 
natomiast moje ambicje są o wiele skromniejsze. Chodzi mi o pełniejszy opis doświadczenia archiwum, o wzbogacenie interpretacji korpusu tekstów o analizę tego, co decyduje o nastroju archiwum, a co równocześnie nie jest do końca sprowadzalne do tekstu bądź reprezentacji. Zakładam, że kwestii nowoczesności w przypadku Francastela nie należy rozpatrywać, ograniczając się do eksplikacji wypowiedzianych wprost poglądów czy wizji świata. Badacz nie tylko wypowiada swoją wizję świata, ale też wytwarza pewną atmosferę, która - nawet jeśli nie jest łatwo deszyfrowalna, nie sprowadza się do jednoznacznego komunikatu - gra rolę w recepcji idei. Zwracam więc uwagę na elementy nastroju archiwum, które określiłbym prowizorycznie jako optymizm i wiara w emancypacyjną moc poznania i doświadczenia sztuki; mają one materialne podstawy, ale nie redukują się do pojęć. Francastel wierzy w pozytywną, transformacyjną moc nowoczesności i wielokrotnie daje to do zrozumienia, niekiedy jednoznacznie (jak wtedy, gdy mówi o postępie w dziedzinie sztuki), a czasem w sposób, który wymyka się interpretacji skoncentrowanej na tekście i pracy pojęć.

Zacznę jednak od interpretacji tekstów; skupię się na tych fragmentach dzieła Francastela, które do tej pory nie były postrzegane jako kluczowe. Jego studia nad nowymi sposobami widzenia konstruowanymi przez medium filmowe są rozsiane w niepublikowanych materiałach archiwalnych i pojedynczych artykułach, co tłumaczy ich niepopularność. Żadna z książek francuskiego autora nie została poświęcona filmowi jako głównemu przedmiotowi badań; nawet wtedy, gdy w Sztuce i technice medium filmowe mogłoby zostać potraktowane jako kluczowe w rozwoju nowoczesnej kultury wizualnej, Francastel ogranicza swoje rozważania do architektury i sfery projektowania.

Większa część badań Francastela dotycząca problematyki widzenia i medium filmowego nigdy nie została opublikowana. Koncepcja francuskiego badacza jest jednak możliwa do odtworzenia dzięki badaniom archiwalnym. Kluczowe dla poniższej rekonstrukcji materiały to przede wszystkim wykłady socjologa prowadzone w paryskim Institut de Filmologie w 1955 i 1956 roku. Najważniejszy z nich, zatytułowany Les problèmes de l'espace filmique, dotyczy charakterystyki widzenia skonfrontowanego z filmem, modelowanego przez film, wreszcie wytwarzanego przez nowoczesne medium. Francastel charakteryzuje to nowe zjawisko, odwołując się, z jednej strony, do relacji widzenia i historii, a także, z drugiej strony, zestawiając film z innymi mediami wizualnymi. Jego pierwszym gestem teoretycznym jest historyzacja: nie sposób zrozumieć widzenia, zakładając jego czasową niezmienność: 
„[...] gdybyśmy patrzyli tak, jak Boticelli albo Rubens, nie bylibyśmy w stanie oglądać filmów"12. To pierwszy krok na drodze przemyślenia widzenia z perspektywy kulturowej, moment zerwania z naturalizmem, w ramach którego widzenie, jako proces zdeterminowany fizjologicznie, mógłby podlegać co najwyżej ewolucji o charakterze biologicznym. Francastel otwiera tym samym drogę takiemu sposobowi myślenia o widzeniu, który wydaje się współcześnie absolutną oczywistością; istotne jest dla mnie, że dokonuje tego przed „zwrotem kulturowym”, przed okresem paradygmatycznej dominacji studiów kulturowych we współczesnej humanistyce, które nie mogłyby funkcjonować w swoim obecnym kształcie bez założenia o historycznej zmienności form widzenia. To właśnie historyczna zmienność widzenia jest podbudową wszelkich perspektyw kulturowych; nie sposób byłoby podtrzymywać tezy o kulturowym charakterze widzenia bez uznania go za fenomen historyczny. Francastel wydaje się jednym z tych myślicieli, którzy niezwykle konsekwentnie i zawsze w powiązaniu z doświadczeniem nowoczesności mówili o wizualności jako modelowanej przez historycznie zmienne formacje kulturowe. Można powiedzieć, że jego propozycja jest bardziej radykalną wersją konstatacji formułowanych w pierwszej połowie XX wieku, np. przez Siegfrieda Kracauera czy Waltera Benjamina pytającego o efekty upowszechnienia się mechanicznych sposobów reprodukcji obrazu. W Dziele sztuki w epoce możliwości jego technicznej reprodukcji historyzacja percepcji i wątek jej przynajmniej częściowej kulturowej determinacji stanowią wstęp do charakterystyki nowoczesnego doświadczenia obrazu. „Sposób ukształtowania się ludzkiej percepcji zmysłowej - medium, w którym ona zachodzi, są uwarunkowane nie tylko przez naturę, ale i przez historię"13. Francastel mówi w zasadzie to samo; teza o kulturowym charakterze percepcji jest jednak u niego wyraźniejsza, ostrzej zarysowana. Przyczyną jest - o ile można tak powiedzieć - jednoznaczność wiary Francastela w nowoczesny postęp. Tam, gdzie Benjamin dopatrywał się paradoksalnej złożoności efektów mechanicznej reprodukcji, francuski socjolog skonstatował - i to pozytywnie - nieuchronność zmian kulturowych. Benjamin daje nam podstawy, by doszukiwać się w jego ujęciu momentów nostalgii, co zostało zauważone

12 P. Francastel Les problèmes de l'espace filmique, maszynopis z poprawkami ręcznymi, 1955-1956, S. 19.

13 W. Benjamin Dzieło sztuki w epoce możliwości jego technicznej reprodukcji, przeł. K. Krzemień, W: Studia z teorii filmu, red. A. Jackiewicz, t. 4: Estetyka i film, Wydawnictwa Artystyczne i Filmowe, Warszawa 1972, s. 155. 
w niektórych współczesnych interpretacjach jego dzieła. David Joselit, który w książce After Art z 2013 roku stawia sobie za cel nowe ujęcie sztuki, architektury i dizajnu w epoce cyfrowej, konstatuje, że „adekwatna ocena sztuki naszych czasów wymaga zerwania z nawykiem nostalgicznego nurzania się w rozpaczy po utracie aury"14. Moim zdaniem francastelowski optymizm zapowiada takie ujęcia jak to proponowane przez Joselita - zrywające z, wydawałoby się, nieuchronnym momentem nostalgii myśli, nakierowane na analizę technicznego kontekstu funkcjonowania sztuki (choć równocześnie niekoniecznie deterministyczne).

Większa część wykładu Les problèmes de l'espace filmique poświęcona jest porównaniu doświadczenia filmowego z doświadczeniem innych mediów, przede wszystkim tych bardziej tradycyjnych, jak malarstwo. Francastel mówi o doświadczeniu filmu, łącząc fenomenologiczną technikę opisu z pojęciami semiologicznymi. Film jest definiowany jako medium wyróżniające się odmiennym od właściwego malarstwu sposobem organizacji przestrzeni i organizacji znakowej. Punktem wyjścia jest dla francuskiego badacza istotowa różnica między malarstwem i medium filmowym, które wymaga odmiennego podejścia i nowego sposobu opisu. Francastel usiłuje uchwycić specyfikę nowoczesnego doświadczenia wizualnego; rozpoczyna od podkreślenia wagi zmiany paradygmatycznej związanej z upowszechnieniem się nowego medium: „[...] perspektywy w filmie nie da się zrozumieć przez pryzmat tradycyjnej perspektywy plastycznej"15. Przestrzeń filmowa jest konstytuowana inaczej, co wynika z nowego rodzaju relacji między widzem i obrazem. „Percepcja plastyczna jest zawsze aktywna. Każda figura jest wieloznaczna. By można ją było rozpoznać, niezbędna jest ukierunkowana aktywność ducha. Wraz z pojawieniem się filmu zmienia się natura tego ukierunkowania"16. Na czym polega owo nowe ukierunkowanie ducha? Otóż widz filmu jest dla Francastela podmiotem pasywnym, podporządkowanym strumieniowi obrazów; jego percepcja nie daje się opisać jako powolne odcyfrowywanie fragmentów nieruchomej, płaskiej powierzchni malowidła. Film sprawia, że percepcja staje się uchwytywaniem szeregu „uporządkowanych i zdeterminowanych przekształcen'"17. 
Nowoczesna wrażliwość konstruowana jest przez doświadczenie filmu. Przed epoką kina relacja między widzem i obrazem była dynamiczna, ale źródło tej dynamiki nie tkwiło w charakterystyce płaszczyzny wizualnej. Brała się ona z koniecznej aktywności sensotwórczej widza, z ruchu spojrzenia usiłującego opanować powierzchnię płótna. Znaki malarskie funkcjonują dzięki swoistemu sposobowi organizacji płaszczyzny - dzięki kompozycji, która sprawia, że oglądający podmiot jest zmuszony do aktywności odczytania: do identyfikowania figur i ich wzajemnych relacji, do odszyfrowywania hierarchii, identyfikowania detali. Tymczasem film wydaje się unieruchamiać widza: jego bierność ma w gruncie rzeczy wynikać ze sposobu organizacji materii wizualnej. Kompozycja poszczególnych obrazów składających się na film jest drugorzędna wobec efektu wytwarzanego przez następowanie po sobie klatek. Zamiast aktywnej analizy statycznej kompozycji dominująca staje się dyspozycja do rozpoznawania tego, co wyłania się z przepływu obrazów: momentów niezmienności składających się na obiekty, postaci, ich materialną i psychologiczną koherentność. To nowy sposób działania percepcji wymuszony przez techniczne właściwości medium filmowego. 24 klatki na sekundę nie dają oglądać się tak samo jak Boticelli czy Rubens, dzięki postępowi techniki mamy do czynienia z zupełnie nowym medium, co sprawia, że patrzymy inaczej. Francastel bierze pod uwagę technikę, ale traktuje ją jako jeden z elementów kształtujących historycznie zmienne modusy widzenia.„Film jest wytworem kamery i jako taki nie jest tylko pojawiającym się na ekranie szeregiem obrazów, ale dziełem sztuki figuratywnej, na którą składają się sądy smaku, sądy co do wartości oraz technika"18. Francastel bardzo wyraźnie zaznacza swój dystans wobec technicznego determinizmu; w jego miejsce proponuje perspektywę par excellence nowoczesną, tzn. taką, w ramach której granica między techniką i sztuką jest do pewnego stopnia zacierana: film ucieleśnia w sobie kolejne udoskonalenia techniczne, postęp techniczny i przemiany percepcji przebiegają równolegle, są nawzajem od siebie zależne. Dzięki temu może pełnić funkcję mediacyjną. Sprawia, że człowiek epoki nowoczesnej jest w stanie zrozumieć postęp techniczny i dostosować się do niego na poziomie percepcyjnym.

Przekonanie o kulturowej determinacji percepcji i jej historycznie zmiennym charakterze sytuowało Francastela w opozycji do wszelkich form realizmu. Na tym tle znacząca jest debata między Francastelem i Michotte van der

18 P. Francastel Cours sur les espaces filmiques, Institut de Filmologie, 2.02.1956, maszynopis z poprawkami ręcznymi, s. 3 . 
Berckiem, która toczyła się na łamach „Revue Internationale de Filmologie” na przełomie lat 40 i 50. i dotyczyła kulturowej i fizjologicznej determinacji widzenia $^{19}$. Artykuł autorstwa Francastela, zatytułowany Espace et illusion zawiera krytyczne uwagi dotyczące "naiwnego realizmu” van der Bercka, czyli przekonania o tym, że obrazy filmowe - nawet jeśli nie funkcjonują dokładnie na tych samych zasadach, co obrazy percypowane w życiu codziennym - wciąż niosą w sobie pierwiastek czy odcisk rzeczywistości. Francastel konsekwentnie obstaje przy perspektywie kulturowej, sprzeciwiając się tym samym jakiejkolwiek możliwości sensownego pomyślenia bezpośredniego doświadczenia rzeczywistości w filmie. „Francastel, przeciwstawiając podejściu do wizualności uprzywilejowującemu fizjologię takie, które traktuje wizualność jako proces tworzenia znaczeń (signification), przyjmuje «kulturalistyczny» pogląd na percepcję, podczas gdy Michotte koncentruje się na mechanizmach fizjologicznych, które traktuje z założenia jako transkulturowe i transhistoryczne. [...] dyskusja przeciwstawiająca sobie historyka sztuki i psychologa"20. Choć stanowisko Francastela jest prekursorskie zarówno wobec strukturalistycznych, jak i współczesnych sposobów myślenia o widzeniu, przede wszystkim tych rozwijanych w ramach studiów nad kulturą wizualną, jego wkład pozostał nierozpoznany. A wystarczy zestawić tę propozycję z mniej lub bardziej udanymi niedawnymi próbami przemyślenia widzenia, by dostrzec wagę tez francuskiego badacza. Kiedy W.J.T. Mitchell próbował w artykule Pokazując widzenie: krytyka kultury wizualnej (czyli ledwie kilkanaście lat temu, w 2002 roku) przedefiniować podstawy reprezentowanej przez siebie dyscypliny, mówi o kluczowym znaczeniu idei konstrukcji widzenia jako zjawiska decydującego teoretycznie: fundującego pewien paradygmat myślenia, umożliwiającego zerwanie z modelem naturalizującym widzenie, a nawet użytecznego heurystycznie i pedagogicznie ${ }^{21}$. Francastel wypowiedział w zasadzie tę samą tezę kilkadziesiąt lat wcześniej; jego perspektywa nie stała się jednak popularna. Nawet we francuskiej filmologii, w ramach

19 Zob. P. Francastel Espace et illusion, "Revue Internationale de Filmologie” 1949 no. 5, s. 65-74; A. Michotte van der Berck A propos de l'étude de M. P. Francastel "Espace et illusion”, ,Revue Internationale de Filmologie" 1949/1950 no. nr 6, s. 139-140. F. Kessler Viewing Change, Changing Views: The "History of Vision" Debate, w: Film 1900: Technology, Perception, Culture, ed. by K. Kreimeier, A. Ligensa, Indiana University Press, Bloomington 2009, s. 24 .

21 Zob. W.J.T. Mitchell Pokazując widzenie: krytyka kultury wizualnej, przeł. M. Bryl, „Artium Quaestiones" $2006 \mathrm{nr}$ XVII, s. 281. 
sporu dotyczącego wrażenia realności w kinie, pozycja kulturowa nie była reprezentowana, a dominującą pozycję zajął bezkrytyczny realizm² ${ }^{22}$.

Kwestia nowego sposobu widzenia wytwarzanego przez medium filmowe jest kluczowa, zwłaszcza że dzięki wydobyciu jej na światło dzienne łatwiej zrozumieć pozycję francuskiego socjologa w linii teoretyków nowoczesności. Francastel nie zajmował się tylko i wyłącznie historią relacji sztuki i techniki; usiłował zrozumieć nowoczesną podmiotowość, jej źródła, formy, dzięki którym się uzewnętrznia. Badania historyczne były dla niego w gruncie rzeczy jedynie punktem wyjścia; celem natomiast - sformułowanie teorii kultury odpowiadającej na wyzwania doby nowoczesności. Historia sztuki, jako dyscyplina niewystarczająco czuła na wyzwania nowych czasów, miała zostać zastąpiona albo co najmniej uzupełniona takim językiem, który byłby w stanie zdać sprawę ze złożoności obiektów funkcjonujących na przecięciu praktyk kulturowych. „Obiekty cywilizacyjne” - bo takie pojęcie u Francastela się pojawia - miały stać się konceptualną alternatywą dla „dzieł sztuki”, czyli przedmiotów przypisanych do konkretnej praktyki kulturowej i czytelnych w ramach historii sztuki. W konsekwencji Francastel mówi o konieczności stworzenia nowej dyscypliny, którą nazywa antropologią kulturową. Miałaby ona być językiem o szerszym zasięgu niż dyskurs historii sztuki, językiem otwartym na analizę praktyk kulturowych w ich różnorodności i wzajemnych relacjach. Historyk sztuki dystansujący się od obiektów tradycyjnie przypisanych jego praktyce (przynajmniej w połowie ubiegłego wieku) i zajmujący się sposobem widzenia konstruowanym przez medium filmowe odpowiada właśnie na tego rodzaju nowoczesne wezwanie. Przypadek Francastela jest egzemplaryczny, gdyż francuski badacz sam przeszedł postulowaną przez siebie drogę; tradycyjne, prowadzone w nurcie pozytywistycznym badania historyka sztuki ustąpiły miejsca szeroko nakreślonej analizie porównawczej nowoczesnych praktyk kulturowych. Francastel porzucił ciasny gorset historii sztuki; zajął się - i to w afirmatywny sposób - kulturą nowoczesną i jej związkami z techniką.

Nowoczesność Francastela - jak już sugerowałem wyżej - nie sprowadza się jednak do pewnego zestawu poglądów, do zbioru idei, które czytelnik mógłby po prostu wyłuskiwać z kolejnych publikacji. Nie można jej zrozumieć, zajmując się tylko i wyłącznie tekstami badacza, niezależnie od ich statusu. Rzecz jasna, zwrócenie uwagi na wątki dotychczas pomijane

22 Zob. Ł. Demby Uśmiech rzeczywistości. O wrażeniu realności w kinie „, Kultura Współczesna” 1994 nr 2. 
w interpretacjach œuvre socjologa jest koniecznym etapem pracy, ponieważ umożliwia rozszerzenie bazy źródłowej i kontekstu interpretacyjnego. Chciałbym zaproponować uzupełnienie tego poszerzonego odczytania o interpretację takich elementów archiwum badacza, które - choć nie są artykułami naukowymi, fragmentami książek ani nawet materiałami przygotowawczymi - wpływają na to, w jaki sposób rozumiemy nowoczesność francuskiego badacza. W pudle archiwalnym oznaczonym numerem 17, zawierającym materiały dotyczące paryskiego Institut de Filmologie, w tym komentowane przeze mnie wyżej wykłady, znajdujemy też materiały będące świadectwem zaangażowania Francastela w projekt nowoczesności, wytwarzające atmosferę zaangażowania: ulotki i foldery pokazów filmów awangardowych, korespondencję dotyczącą filmów Johna i Jamesa Whitney, wycinki prasowe dotyczące filmologii, wreszcie korespondencję wokół przedsięwzięcia filmologicznego.

W jaki sposób tego rodzaju materiały mogą uzupełnić interpretację tekstów? Wpływają one na to, w jaki sposób wygląda doświadczenie archiwum, o którym zwykliśmy myśleć w perspektywie relacji porządku i chaosu, wiedzy i niewiedzy, obecności i nieobecności. Zarówno perspektywa pozytywistyczna (archiwum jest gwarantem wiedzy), jak i konstruktywistyczna (archiwum jest sposobem konstrukcji wiedzy) jest skoncentrowana na kwestiach epistemicznych, na możliwości bądź niemożliwości dotarcia do źródła, które ma uprawomocnić wydawane sądy. Tymczasem wskazane przeze mnie materiały nie wpisują się - przynajmniej nie do końca - w tę logikę. Owszem, można na ich podstawie zrekonstruować fakty, ale ich wartość leży gdzie indziej.Jak pokażę, są one materialną podstawą nastroju archiwum, który jest istotny dla tego, w jaki sposób je odbieramy.

Pudło archiwalne gromadzące materiały związane z działalnością Francastela w Institut de Filmologie zawiera wiele dokumentów, które nie mają wyraźnego związku z działalnością instytutu; są raczej świadectwem wyjątkowego stosunku Francastela do filmu iXX-wiecznej sfery medialnej w ogóle. Uwagę zwracają foldery pokazów filmów awangardowych, esejów filmowych i filmów z okresu początków kina. Najwcześniej datowane materiały z pudła wyprzedzają w czasie istnienie powołanego w 1950 roku Institut de Filmologie: $\mathrm{z}$ listopada 1948 roku pochodzi ulotka zapowiadająca pokazy z początku epoki kina w Cinémathèque Française. Na marginesie szczegółowego spisu prezentowanych dzieł znajdujemy inskrypcje Francastela wskazujące na filmy, które badacz już widział i te, które ma dopiero zamiar obejrzeć. Długie szeregi nazwisk reżyserów i tytułów (kompletny spis wraz z podstawowymi 
informacjami na temat każdego obrazu), wydrukowane na równych kolumnach, są uzupełnione odręcznymi zapiskami. Zgodnie z moją propozycją interpretacyjną folder ten nie jest tylko i wyłącznie dokumentem odnoszącym się do przeszłego stanu rzeczy, ale materialnym śladem zaangażowania Francastela w projekt nowoczesny, elementem kreującym nastrój archiwum. Dla tego, kto pracuje w archiwum, szybko staje się oczywiste, że badacz nie traktował filmu neutralnie. Łatwo zdać sobie sprawę ze stawki doświadczenia kina, przede wszystkim awangardy filmowej jako obrazu formującego na nowo spojrzenie, modelującego percepcję człowieka nowoczesnego. Kolejne foldery, które znajdujemy w teczce, zawsze opatrzone osobistymi adnotacjami, potęgują to wrażenie. Istotne znaczenie ma tu liczba dokumentów: na atmosferę zaangażowania składa się też wrażenie pełności czy systematyczności, które wykluczają jakąkolwiek przypadkowość zbioru. Francastel nie „interesował się kinem”, nie „spędzał czasu wolnego”, oglądając dzieła światowej kinematografii, ale metodycznie studiował najważniejsze dzieła z okresu początków kina i klasykę filmografii awangardowej, by lepiej zrozumieć to, w jaki sposób współczesna kultura wchodzi w związki z techniką.

Atmosfera zaangażowania jest wytwarzana w archiwum Francastela również na inne sposoby. Korespondencja dotycząca filmów Johna i Jamesa Whitney jest tu egzemplaryczna: pokazuje, że badacz zainteresowany był przede wszystkim tymi obszarami we współczesnej mu działalności artystycznej, na których sztuka i technika przenikają się. W paryskim archiwum znajdujemy list z 23 lipca 1948 roku adresowany do Francastela, napisany przez przedstawiciela stowarzyszenia „Les Amis de l'Art”, z informacjami dotyczącymi twórczości braci Whitney. Autor listu wspomina o urządzeniu do tworzenia filmów abstrakcyjnych i o eksperymentach łączących film i muzykę. Do napisanego na maszynie listu dołączona jest odręczna notka z bardziej szczegółowym opisem medium: mowa jest o sposobie łączenia filmu i muzyki, użyciu syntezatorów, pojawia się termin "muzyka wizualna” na określenie wzajemnej zależności (rytmicznej) obrazu i dźwięku. Ta część archiwum wydaje mi się tak samo ważna jak zbiór wykładów: choć nie mamy tu do czynienia z tekstem, z prezentacją poglądów, możemy zrekonstruować nastawienie badacza wobec sztuki: ciekawość wobec zjawisk, które wydają się definiować przyszłość kultury, zainteresowanie szczegółami technicznymi i materialnymi warunkami możliwości nowych zjawisk na pograniczu muzyki i obrazu, potrzebę eksplorowania nowych terytoriów między utrwalonymi dziedzinami. Moim zdaniem najważniejszą cechą tych fragmentów archiwów jest właśnie zdolność do ewokowania pewnego stanu emocjonalnego, 
nastawienia, trudnego do nazwania nastroju, który równocześnie uzupełnia to, co w archiwum jest powiedziane czy napisane wprost i wpływa na to, w jaki sposób jest ono odbierane.

Dzięki doświadczeniu nastroju archiwum o wiele łatwiej zrozumieć nam nowoczesność Francastela; pod tym pojęciem nie kryją się tylko i wyłącznie idee dotyczące sensu historii, ale także pewnego rodzaju nastawienie wobec tego, co współczesne, nastawienie, którego nie bylibyśmy w stanie opisać, nie zwracając uwagi na atmosferę unoszącą się nad zbiorami archiwalnymi. Nowoczesność jest z tej perspektywy na trwałe związana z poczuciem konieczności zaangażowania, z entuzjazmem wobec przyszłości, z pozytywnym nastawieniem wobec tych zjawisk artystycznych, które ucieleśniają postęp rozumiany jako równoległe przemiany w technice, kulturze i sposobach myślenia o świecie. Zgodnie z moją hipotezą dopiero rekonstrukcja owego nastroju pozwala na właściwe ujęcie zarówno pojęć tworzących rdzeń projektu Francastela, jak i jego zaangażowania w inicjatywy instytucjonalne. Mam tu przede wszystkim na myśli studia kinematograficzne, które otrzymały we Francji postać instytucjonalną dzięki powstaniu w 1948 roku (i oficjalnemu powołaniu w 1950 roku) Institut de Filmologie, struktury osadzonej w ramach Sorbony. Sam termin filmologia jest nieco wcześniejszy - jak zauważa Martin Lefebvre, pojawia się on po raz pierwszy w 1947 roku w tekście Gilberta Cohen-Seata zatytułowanym Essai sur les principes d'une philosophie du cinéma. Tome I, Introduction générale. Notions fondamentales et vocabulaire de filmologie ${ }^{23}$. Francastel stał się członkiem zespołu badaczy wspierających filmologię jako nową naukę; jak dowodzi zgromadzona w archiwum korespondencja, był aktywnym współpracownikiem instytutu. Począwszy od 1948 roku, prowadzi wykłady dotyczące m.in. przestrzeni w filmie, iluzji, następstwa obrazów, ru$\mathrm{chu}^{24}$. Analizowane przeze mnie wyżej fragmenty wykładów, ale także wymiar zaangażowania Francastela w przedsięwzięcie filmologiczne, zakres jego zainteresowań, dobitnie świadczą o tym, że badacz dostrzegał konieczność pracy nad nowym językiem mówiącym o tym, co dziś nazywamy kulturą wizualną. Historia sztuki z tej perspektywy jest językiem, który należałoby

23 Zob. M. Lefebvre L'aventure filmologique: documents et jalons d'une histoire institutionnelle , Cinémas" printemps 2009 vol. 19, no. 2/3, S. 59; G. Cohen-Seat Essai sur les principes d'une philosophie du cinéma, tome I: Introduction générale. Notions fondamentales et vocabulaire de filmologie, "Les Études Philosophiques" 1947 vol. 2 (2). -316. W artykule F. Albery znajdujemy wyczerpujące wyliczenie aktywności Pierre'a Francastela $w$ ramach przedsięwzięcia filmologicznego. 
przekroczyć: skoro nie jest ona w stanie zdać sprawy z tego, w jaki sposób postrzegamy świat, jej miejsce musi zająć perspektywa zakorzeniona we współczesnych praktykach widzenia.

Na podstawie powyższych obserwacji staje się oczywiste, że z perspektywy Francastela medium filmowe definiowało nowoczesność. To stąd wzięło się przekonanie o konieczności transformacji dyskursu mówiącego o wizualności, o konieczności krytyki historii sztuki i przekroczenia jej granic. Transformacje języka filmowego były równocześnie transformacjami sposobów widzenia. Rozpoznanie istotności filmu nie sprawiło jednak, że francuski badacz przestał zajmować się sztuką. Przeciwnie: Francastel był zawsze przekonany o kluczowej roli historycznego ugruntowania nowoczesności, co nie byłoby możliwe bez rozpoznania przemian dotykających twórczość artystyczną. Niektóre spośród wizji nowoczesności były dla Francastela nieakceptowalne ze względu na ich niewystarczające zakorzenienie w historii. Znaczące były jego uwagi wymierzone w koncepcję Siegfrieda Giediona, któremu zarzucał niepoddający się weryfikacji idealizm. Yve-Alain Bois niezwykle celnie zwraca uwagę na to, że francuski badacz był w zasadzie przeciw każdej dotychczas powstałej wizji technicznej nowoczesności, przy czym najwyraźniej zaznaczył się jego sprzeciw Mumfordowskiej mistyce postępu i koncepcji rewolucji przemysłowej jako momencie przełomu ${ }^{25}$. Tymczasem Francastel opowiadał się za koncepcją nowoczesnej ewolucji nasilającej się równolegle $\mathrm{w}$ różnych sferach kultury, w społeczeństwie i w technice, oraz za badaniem relacji łączących fenomeny przynależące do różnych sfer. W archiwum zgromadzonym w INHA znajdujemy świadectwa badań dotyczących artystów, którzy wpisywali się w tę wizję. W pudle archiwalnym oznaczonym numerem 22, zawierającym teksty książek przygotowywanych do druku i przedmowy do reedycji książek, znajdujemy materiały do książki o Robercie Delaunay. Została ona ostatecznie wydana w 1957 roku; Francastel został redaktorem tomu zawierającego teksty artysty oraz katalog jego dzieł ${ }^{26}$. Komentarze Francastela pokazują, że widzi on w dziele Delaunaya tę samą zdolność do przekształcania sposobu patrzenia na świat, którą przypisuje kinu. „Począwszy od 1912 roku Delaunay pokazuje, że ludzkie oko uchwytuje bezpośrednio formy świetlne, które przekazują takie jakości materii jak prędkość, barwa, relacje ze światłem. Pokazał też, że malarstwo pozwala

25

26

Zob. Y.A. Bois Foreword, w: P. Francastel Art \& Technology..., s. 8.

R. Delaunay Du cubisme à l'art abstrait; documents inédits publiés par Pierre Francastel et suivis d'un catalogue de l'œuvre de R. Delaunay, S.E.V.P.E.N., Paris 1957. 
ludziom tego czasu na ucieleśnienie w znakach, owych przekaźnikach komunikowalnego doświadczenia, nowego, zmysłowego sposobu rozumienia świata, który nas otacza. Nie da się zrozumieć naszych czasów bez wzięcia pod uwagę badań w dziedzinie sztuki"27. Francuski malarz - równolegle wobec postępu w innych dziedzinach kultury, w tym w kinie - przekształca malarstwo w praktykę badawczą, sprawia, że człowiek nowoczesny rozumie nowy kształt świata, mediuje postęp techniczny i wcześniej niedostępne wymiary rzeczywistości. Entuzjazm Francastela w obliczu dzieła Delaunaya jest uderzający: teoretyk używa tej samej retoryki, którą stosuje, gdy rozprawia o medium filmowym. Dowodzi w ten sposób, że jego perspektywa nie opiera się na fetyszyzacji nowego medium, ale na uważnej obserwacji tych zjawisk kultury, które pozwalają inaczej zobaczyć świat. „Sztuka Delaunaya przynosi obietnicę i pierwsze próby sztuki nowej, dzięki której nowoczesny człowiek w twórczy sposób wyrazi swoje wrażenia i myśli"28. Przy czym nowoczesność nie jest tu tylko i wyłącznie kwestią wizji świata (wizji, w ramach której człowiek identyfikuje się z postępem), ale też nacechowania emocjonalnego. Nie ma nowoczesności bez nastroju: bez entuzjazmu, który wiąże człowieka z wizją przyszłości. 


\section{Abstract}

\section{Andrzej Leśniak}

THE INSTITUTE OF LITERARY RESEARCH OF THE POLISH ACADEMY OF SCIENCES (WARSAW)

An Atmosphere of Modernity: The Experience of Film, New Ways of Seeing and Optimism in the Archive of Pierre Francastel

Leśniak reads the works of French art sociologist Pierre Francastel in relation to the notion of atmosphere. Leśniak argues that besides analysing previously unpublished documents from Francastel's archive - including unpublished texts on the experience of film - scholars should also direct their attention to the atmosphere of the archive - the material traces of modern optimism, evidence of faith in progress. This kind of research makes it possible to think of modernity in terms of affect.

\section{Keywords}

Pierre Francastel, atmosphere, optimism, modernity, archives, cinema, film studies 